Jorge Urdánoz ${ }^{\mathrm{ab}}$

${ }^{a}$ Communitas. Institute for Advanced Social Research, Philosophy of Law Department, Universidad Pública de Navarra, Pamplona, Spain.

${ }^{b}$ Political Science Department, Universidad Nacional de Educación a Distancia, Madrid, Spain.

Jorge.urdanoz@unavarra.es

This work was supported by the Spanish Government under Grant DER201569217-C2-1-R.

Jorge Urdanoz is Professor of Political Science in the Universidad Nacional de Eduación a Distancia (UNED, Madrid) and professor of Philosophy of Law in the Universidad Pública de Navarra (UPNA, Pamplona). He has been Visiting Scholar in Columbia University (sponsor Nadia Urbinati) and in the New York University (sponsor Steven Brams). His main research topics are political representation, electoral systems and theory of democracy. He has published several books and articles.

https://scholar.google.com/citations?user=MHCo5i4AAAAJ

https://orcid.org/0000-0002-5296-1589 


\title{
John Stuart Mill and Proportional Representation. A misunderstanding.
}

\author{
ABSTRACT \\ Mill scholars usually classify as "proportional" the theory of political \\ representation sustained by John Stuart Mill. However, Mill did not use the term \\ "proportional" in his texts, and "proportional representation" as understood today \\ has little to do with what Mill really proposed. A hypothesis is offered to explain \\ the origin of the "proportionalist" interpretation that was accepted \\ at the beginning of the 20st century. It is concluded that specialists in Mill \\ should not use the word "proportional" when referring to his conception of \\ political representation. In addition, political scientists should not quote Mill as \\ the founder of proportional representation.
}

Keywords: Proportional representation, John Stuart Mill, political participation, electoral systems, majority government. 


\section{Mill in his context.}

John Stuart Mill is widely considered to be the founder of proportional representation ${ }^{1}$. However, the relationship between Mill and proportionality is far from clear. In this paper, I aim to put forward an idea similar to Colomer (2007) when he dealt with Mirabeu claims. Mirabeau has been considered an early supporter of proportionality, largely due to his statement, "the Estates-General should be to the nation what a chart is to its physical configuration; in all its parts and as a whole the copy should at all times have the same proportions as the original" (Mirabeau, 1789, pp. 7-8). Although this passage can be interpreted as a statement in favour of the principles of proportional representation, Colomer raises the following two objections (Colomer, 2007).

First is related to the translation. Mirabeau never actually said "the EstatesGeneral should be to the nation (like a chart)", the usual translation, but "the Estates-

${ }^{1}$ Nagel (2001:12216) distinguishes between "proportional representation" as applied to specific electoral systems and "proportionality", the representative ideal to which those electoral systems aim. Mill enthusiastically advocated an electoral system, the Hare system. Since then, almost every political science or political philosophy contribution on the topic of political representation published throughout the last century (from Humphreys, 1911:198 to Ryan, 2014:11) considers him a supporter of the ideal of "proportionality". Even Wikipedia affirms, in its entry on "proportional representation", that "the case for proportional representation was made by John Stuart Mill in his 1861 essay Considerations on Representative Government", (accessed July 7, 2019). 
General are to the nation (like a chart)"2. The second objection is hermeneutic. The debate about proportional electoral rules did not start until several decades later.

Colomer's interpretation puts Mirabeau in context. He wrote under specific circumstances, the election of provincial representatives to the French Estates-General on the eve of the Revolution of 1789 , and only from that particular situation can we interpret these words. Thus, "we should acknowledge that no explicit reference to new electoral rules of proportional representation was ever made by Mirabeau" (Colomer, 2007: 270).

These objections can also be raised against a certain proportionalist interpretation of Mill. Several quotes are frequently offered as a proof of his support to proportionality:

In my conviction, Mr. Hare's plan [is] among the very greatest improvements yet made in the theory and practice of government. In the first place, it secures a representation, in proportion to numbers, of every division of the electoral body. (Considerations, C.W. XIX: 424) ${ }^{3}$.

In a really equal democracy, every or any section would be represented, not disproportionately, but proportionately. A majority of the electors would always have a majority of the representatives; but a minority of the electors would

2 Colomer (2007:269) mentions several incorrect translation examples: Hoag and Hallett (1926), Ian McLean, (1991) and Colomer (2001). However, the misinterpretation is even older (Sterne, 1871: 50). In 1969, Pitkin was already conscious of the problem (Pitkin, 1969: 263).

${ }^{3}$ All page references to the writings of Mill are to the Collected Works of John Stuart Mill, 33 volumes, John M. Robson, General Editor, Toronto, University of Toronto Press, 1963-91. I include the corresponding book or letter in Italics. 
always have a minority of the representatives. Man for man they would be as fully represented as the majority. (Ibid: 449)

It must be remembered that the influence of the two great parties, under the present mode of election, is unlimited: in Mr. Hare's scheme it would be great, but confined within bounds. Neither they, nor any of the smaller knots, would be able to elect more members than in proportion to the relative number of their adherents (Ibid: 463).

The minor groups would have precisely the amount of power which they ought to have. The influence they could exercise would be exactly that which their number of voters entitled them to; not a particle more (Ibid: 464).

How can it be doubted, after these conclusive declarations, that Mill consistently supported the proportional representation ideal? The main issue here is one of anachronism (Skinner, 1969). From the 21 st century we think of the 19 th century British Parliament in terms of "parties," "majority" and "proportionality". However, such conceptual configurations were somewhat alien to Mill. He used the terms "majority" and "minority", but he did not understand them in the same way we currently do. The terms are identical, the meanings differ.

We can observe in Mill, as in Mirabeu, certain misunderstandings in the translation. In Considerations on Representative Government the term "proportional representation" appears only on one occasion (Considerations, C.W. XIX, p. 477). The term he actually used was "Personal representation". In all his books, letters, public speeches and in his autobiography, Mill always used the term "Personal representation" to describe the Hare system. Despite this, all his work is known today thanks to the 
word "proportional" - rather than "Personal"—representation. That is the way Mill is usually translated ${ }^{4}$.

What was the electoral system that Hare invented? To answer this question, it is necessary to examine the electoral rules that were in force in 1860 , that is, the electoral system against which both Mill and Hare offered their alternative. At that time, the 658 Parliament members were elected by plurality rule in uninominal districts. There were also a few binominal and trinominal districts, in which the two or three candidates with the most votes were elected. This electoral system, which Colomer calls the Originating system (2007: 265), was the object of numerous criticisms. Mill insisted on the following three:

(1) It does not represent the defeated minorities within each district. As a result, not all electors are represented.

(2) The victorious majorities are not correctly represented either, being only allowed to select between candidates imposed by party machinery.

(3) It does not satisfy the majority principle. Since the 658 Parliament members only represent the voters from the 658 majorities (and not all the electors), each

${ }^{4}$ This happens even with the presentation of his work. For instance, the conference originally titled "The Redistribution of Seats/Conference at the Reform League Rooms" is titled in Mill's Collected Works as "Proportional Representation and Redistribution" (C.W. XXVII: 239). However, the expression "Proportional Representation" does not appear in the text. It is in the mind of the editors, but not in Mill's work and, as I intend to show, was not in Mill's thought either. 
decision they take in the chamber will only represent the majority of those local majorities, not the majority of the country.

Hare is usually regarded as the inventor of the Single Transferable Vote (STV), the electoral system in force today in Ireland and Malta, widely considered the "theoretically optimal form of PR in the opinion of the academics" (Lijphart and Grofman, 1984, p. $17^{5}$ ). However, when Mill defended the Hare System, he was not thinking exactly of STV. Hare's original proposal was for the 658 members of parliament to be elected in a "national" district, much like the current electoral system in the Netherlands. Of course, here is a crucial difference. In the Netherlands, electors vote for parties, and every party receives a proportion of seats in proportion to its votes. Hare, however, loathed parties. His proposal was designed to allow citizens to vote for candidates as individuals, hence the term "Personal Representation".

Under his plan, electors had to vote for their preferred candidates, ranking them on the ballot paper. Each elector could rank up to 658 names. First, the necessary quota to obtain a seat was determined (the later famous Hare quota, representing the $658^{\text {th }}$ part of the votes). Secondly, thanks to a transfer mechanism for the surplus votes, the 658

5 This opinion has changed today. According to a 2005 survey conducted among 170 electoral systems scholars, STV was the second most preferred option out of nine main categories of electoral systems. The first one was mixed-member proportional systems (Bowler, Farrel and Pettit, 2005: 7). 
winning candidates were designated ${ }^{6}$. In this paper we will assume that the quota is equal to 3,000 votes, in the same way that Mill did (Speech, C.W. XXVIII: 179).

The elector could vote not only for district candidates, but for candidates from all over the country. In this way, each representative would represent his "voluntary constituency", that is to say, his 3,000 voters. Instead of dividing the country into 658 geographical districts, the Hare system was thought to divide it into 658 "voluntary constituencies," each formed by 3,000 voters represented by their Personal Representative. This is the system Mill promoted, and is the system we must bear in

${ }^{6}$ According to Hare's system, voters indicate on their ballot papers their orders of preference for each candidate. Any candidate who receives the quota with the first preferences is elected. If a candidate receives more than the established quota, his surplus is transferred to the candidates who come out with the second choice on the surplus ballots. This process continues until 658 candidates reach the quota and are elected. This peculiar transfer mechanism achieved more notoriety than any other aspect of the proposal. Both systems share such a mechanism, and this is probably the reason for the confusion arising between the Hare system and the later STV. The main difference between them is that the Hare system permitted electors to rank order for up to as many as 658 candidates, being the whole country a sole district. Modern STV, however, uses geographic districts, usually between three and seven representatives. Versions of STV are today used for national elections in several countries: in Ireland and Malta for lower house elections, in Northern Ireland for local, European and Assembly elections, in Australia and India for their upper houses, in Australia for some regional elections and in Scotland and New Zealand for local government elections (Mitchell 2014:247). 
mind when reading the Considerations and the other texts in which Mill supported electoral reform (Hart, 1992: 24-54).

While our concepts of "majority" and "proportionality" are applied to parties, Mill envisaged a parliament of individuals. Moreover, a parliament in which every representative has his 3,000 voters in a voluntary constituency seems to fall outside our idea of "proportionality". To avoid ambiguity, I will differentiate each perspective with a different title:

- On the one hand, we have the current perspective, "proportionalism". From this point of view minorities of the whole country have a variable weight and therefore need to be represented by a varying proportion of seats, a task only a party is able to carry out.

- On the other hand, we have Mill's perspective, which I will call "quotism". Here, under the Hare system, electors could join together and obtain a representative. As a result, each successful group (or quota) of electors has the same size, and is represented by a personal representative. As long as electors vote only for personal candidates, parties are unnecessary.

One will now perhaps have a different perspective when reading Mill on the Hare system. Let us take, for instance, this quotation:

"In my conviction, Mr. Hare's plan [is] among the very greatest improvements yet made in the theory and practice of government. In the first place, it secures a representation, in proportion to numbers, of every division of the electoral body". 
We invariably read this fragment today as an explicit confirmation of Mill's defense of proportionality. However, "in proportion to numbers" does not necessary imply "proportional representation". If we read the complete quotation, it seems clear that every minority reaching the quota will get one representative (and no more):

“ (...) it secures a representation, in proportion to numbers, of every division of the electoral body: not two great parties alone, with perhaps a few large sectional minorities in particular places, but every minority in the whole nation, consisting of a sufficiently large number to be, on principles of equal justice, entitled to a representative. (Considerations, C.W. XIX: 424, emphasis added).

This personal representation is undoubtedly "in proportion to numbers," but is far from being equivalent to the widely held concept of proportional representation. When we read Mill writing in terms of "quotism," and not through the paradigm of "proportionalism," things appear considerably different.

\section{1.- Proportionalism vs. quotism}

The main difference between proportionalism and quotism can be described as follows: under a proportional system, electors form groups around different parties and, a posteriori, the parliament is constituted according to them. The parliamentary groups are shaped according to the decisions of the voters. If party A gets $7 \%$ of the votes, then its parliamentary group will have $7 \%$ of the seats. Under a quotist system, it is quite the opposite: the parliament is, a priori, composed of 658 seats, and each of them is going to represent the same number of voters: exactly 3,000. It is now the voters who must adapt to the parliamentary disposition of seats. They have to group themselves in order to become represented by one seat or another. The voters have to proportionally 
represent the seats, although this verbalization may seem rather strange.

Indeed, the "transferable" votes on the ballot paper are nothing more than a designation of possibilities, indicated by the elector, to be represented by one or another candidate. If one's first option is already elected, then his or her vote will go to the second option; if this option is also elected, then it will go to the third, and so on. It is the elector who must "move" from one to another representative, looking for a seat in which his vote may be accepted, and hence represented.

Although this cannot be considered "proportional representation", when contrasted with the Originating system, the advantages were nonetheless clear:

(1) Everybody was represented.

(2) Every voter was represented by someone he chose, and for whom he voted.

(3) Everybody was represented "in proportion to numbers".

(4) The parliamentary majorities always represented an electoral majority.

Today we mistakenly contextualize these four properties, which Mill incessantly brandished against the Originating system, within a proportionalist and party-oriented conception. However it is nonetheless true that the quotist and Personal representation concept satisfies all four. Our categories of "majority" and "proportionality," which Hare and Mill never got to know, impede our full understanding of Mill's thought.

\section{2.- Against proportionalism}

Of course, it can be alleged that, if people vote along party lines (if parties print their own ballots with their candidates in the same order, and electors use them) then the parliament will have a purely proportional representation: each party will receive a 
strength in seats proportional to its strength in votes. Certainly this contingency might legitimate the proportional interpretation. However, Hare and Mill expressly rejected such a version. In 1866, Bagehot presented this possibility as an objection. Although he conceded to recognize several advantages in Hare's plan, the mere possibility of a proportional party representation was reason enough for him to reject it:

The evident result of this organization would be the return of party men mainly (...) They would write to gentlemen in Parliament, and say, "You were elected upon 'the Liberal ticket;' if you deviate from that ticket you cannot be chosen again". And there would be no appeal for a common-minded man. He is no more likely to make a constituency for himself than a mole is likely to make a planet" (Bagehot, 1873: 216, 219).

Both Hare and Mill took it for granted that the electorate would never tolerate such electoral behaviour ${ }^{7}$. Hare affirms: "How alien all this management is to our habitual action,- - how irreconcilable with our forms of political life!" (Hare, 1873: 15). Mill asserts that electors would never accept the "party ticket":

${ }^{7}$ Both men were mistaken here. Bagehot was right to assume that ranking a huge number of personal candidates is beyond the cognitive capacity of electors. The Australian Senate offers an empirical confirmation: the electoral system may require voters to rank thirty or more individual candidates, but in 1984 the Group Vote Ticket (also known as' above the line voting') was included. Since then, over $90 \%$ of electors rely on tickets previously prepared by their political parties (Economou: 2016:117). 
“...on Mr. Hare's system, a vote given to a person of known worth has almost as much chance of obtaining its object as one given to a party candidate. It might be hoped, therefore, that every Liberal or Conservative, who was anything besides a Liberal or a Conservative-who had any preferences of his own in addition to those of his party-would scratch through the names of the more obscure and insignificant party candidates, and inscribe in their stead some of the men who are an honor to the nation" (Considerations, C.W. XIX: 464).

That is the basic (and sufficient) reason, but there is a misunderstanding here. The essence of his answer is that such behaviour would never be widely accepted. Yet he continues by explaining that if it were the case (if parties were to print ballots and all the electors used them), that contingency (the pure proportionalist hypothesis) would be in itself better than the Originating system. The grading of systems, from worse to best, is this: Originating system, Proportional system, Personal system. It is here, in this passage, where we find the quotations in which Mill comes out himself most purely as a proportionalist:

"It must be remembered that the influence of the two great parties, under the present mode of election, is unlimited: in Mr. Hare's scheme it would be great, but confined within bounds. Neither they, nor any of the smaller knots, would be able to elect more members than in proportion to the relative number of their adherents" (Considerations, C.W. XIX: 463).

"The minor groups would have precisely the amount of power which they ought to have. The influence they could exercise would be exactly that which their number of voters entitled them to; not a particle more" (Considerations, C.W. XIX: 464).

Here proportionalism is explicit: he is talking about "parties," "knots" and "groups", not about personal representation. However this should not be taken out of context. Mill is simply replying to Bagehot. The hypothetical situation presented to Mill 
(that is, proportionalism), although preferable to the existing system, was not what he advocated. His system was not thought to facilitate such a possibility. Indeed, Personal representation was specially thought of as a device against party representation. Mill's evident aversion to parties, especially to "party machinery", frequently can be seen his texts (Thompson, 1976).

Mill even offers in the Considerations a reform of the Hare system in order to make impossible the party ticket, although only if it "should it be necessary to resort to it" (Considerations, C.W. XIX: 464). Such reform consists of limiting the number of "secondary" or "contingent" ("transferable", we say today) votes from twenty to fifty. In that way each party would be unable to print ballots with 658 names, but only with twenty or fifty, and as a result each party could each only obtain twenty or fifty seats at most. The other seats in the parliament would be occupied by personal candidates. The decisive aspect here is the progression. Mill thinks that such a thing will never happen; and, just in case it occurs, he proposes a reform in order to make it impossible. Such a possibility — the one Mill hoped would never occur and the one he tried to avoid — is exactly what we call "Proportional Representation" today.

\section{2.- Minorities, majorities and objective counting}

This quotist perspective also implies a different comprehension of the concepts of "minority" and "majority" in Mill. When Mill talks about minorities, his notion of the term is not the one we normally have in mind. For us, "minorities" are homogeneous groups of voters with minor electoral support in the country as a whole. Most representative democracies currently include several minorities, normally from about one to ten. To Mill, however, there are always 658 minorities after an election. 
When Mill talks about "minorities", he is speaking of the electors who, within each district, have been defeated. Under the Originating system, those minorities are not represented in the parliament. The Hare system did enable them to be represented, but not proportionally, at least not as we now understand the term. It was able to represent minorities not by giving them a number of seats proportional to their weight in the country as a whole (if you get $5 \%$ of the votes, then you deserve $5 \%$ of the seats), but because if several local minorities joined a candidate and reached the quota, they would then be represented by that candidate. This is what "in proportion to numbers" means to Mill, although we almost invariably interpret it another way. We interpret the term "minorities" to mean "minorities in the whole country," minorities with 3,5 or $8 \%$ of the votes. Consequently, we read the expression "in proportion to numbers" under the desideratum that each minority should receive a number of seats proportional to that percentage: 3,5 or $8 \%$ of the seats, respectively. Nevertheless, it is hard to believe Mill could have been thinking this way, since such a hypothesis requires the presence of political parties, and the Personal Representation system was specifically devised to diminish or even eradicate the burden of party machinery.

Also central to Mill's approval of Hare's system is the majority principle. He constantly denounces what he perceives as an obvious defect of the Originating system. Since it does not represent all voters, laws passed in Parliament could be supported by less than half of the electorate. Therefore, Mill says, "unless minorities are counted the majority which prevails may be but a sham majority" (Speech, C.W. XXVIII: 184). This is going to be one of Mill's main lines of reasoning (shared by all the critics of the Originating system). Let us suppose, for example, that a party receives $30 \%$ of the votes. If its supporters are scattered, it is possible that the party could get no seats. As a 
result, only $70 \%$ of the electors would be "counted". Each majority of votes in the parliament would only represent then $35 \%$ of the electors, and not the majority of them.

Today, we can only understand those lines through the proportionality paradigm filter. We have no other linguistic (and thus conceptual) tools. Let us imagine a perfectly proportional representation. Under this scheme, a majority in the Parliament is always a majority in the electorate. However, and this is critical, the opposite is also true: only if the representation is proportional is it possible to apply the majority principle.

Under this configuration, parties monopolize representation. Again we find all elements of the proportionalist view: the parties receive the votes from the whole country in variable proportions. Accordingly, if a decision in the parliament has to be consistent with the majority principle, the only solution is to proportionally represent each political party.

This way, since we understand "representation" as "party representation," we are bound to interpret Mill in proportionalist tones, even when he is using a majoritarian argument. Let us examine the following quotations:

In a really equal democracy, every or any section would be represented, not disproportionately, but proportionately. A majority of the electors would always have a majority of the representatives; but a minority of the electors would always have a minority of the representatives. Man for man they would be as fully represented as the majority (Considerations, C.W. XIX, p. 449).

It is not only a minority who suffers. Democracy, thus constituted, does not even attain its ostensible object, that of giving the powers of government in all cases to the numerical majority. It does something very different: it gives them to a majority of the majority; who may be, and often are, but a minority of the whole (Considerations, C.W. XIX, p. 449). 
When we read these fragments today, our perceptions are unconsciously being filtered through our previous notions of proportionality and majority, brought about by the party representation paradigm. The projection is so powerful that, to our eyes, only by means of the proportional ideal is it possible to "count" all the votes in the country. An operation as basic as mere counting, apparently objective and impartial, is conceived only under the (normative) paradigm of proportionality.

Mill also used the verb "count". One of his famous quotations states that "majorities are never sure of outnumbering minorities, unless every elector is counted". But we should be aware that the "count" here is not of votes for parties. The complete quotation is this:

"Majorities are never sure of outnumbering minorities, unless every elector is counted - unless every man's vote is as effective as any other man's in returning a representative. No system but that which that I am submitting to the House effects this, because it is the only system under which every vote tells, and every constituency is unanimous" (Speech, C.W. XXVIII, pp. 184-185, emphasis added).

This way of "counting" does not tie in correctly with the conceptual model of proportionalism. Every elector has to be counted, but to be represented by "a" representative (and only by one). Every elector has to be counted in parliament, but in "unanimous" constituencies. Today we lack a term, a figure, a conceptual formula embodying the possibility of counting every vote, outside the proportional-party frame. The only way we can currently conceive of to get everybody represented (everybody counts), equally represented (everybody counts the same), and thus to elect a government for the majority is by means of proportional representation...by parties. Yet identical virtues are provided by the "quotist" representation: everyone is represented, 
equally, with a majority of seats always representing a majority of the electorate. The majority principle is thus safeguarded.

There is, however, a crucial difference between both perspectives. In the partycentred one, divisions are fixed after each election. A day after the election, minorities and (the possible) majority can be easily determined in Parliament. Mill, however, denounced "at least 500 times $[\ldots]$ the greatness of the mistake of supposing that the country was divided into a majority and a minority, instead of into majorities and minorities" (The Reform Bill, C.W. XXVIII: 208). To Mill, the majority is not something which appears after the election day (a "liberal or conservative majority"), but an opinion which emerges in the chamber as each new issue requires a vote. Contrary to our parliamentary majorities and minorities (reflecting the different electoral sections as determined by electors on the election day, for the rest of legislature), Mill believed in deliberative majorities and minorities, which would reflect in the chamber the result of discussion and debate, emerging and reshaping with each new parliamentary decision.

\section{3.- Deliberation vs. proportionality}

Until now, the Hare system has been examined only from an "electoral" perspective. When we consider Mill's theory of Representation the proportionalist reading attributed to him becomes even less plausible. Usually, quotations supporting such reading are extracted from chapter seven of the Considerations. But all the proposals in the chapter have to be read in light of the former chapter in which Mill warns of the two major dangers of representative government, the two that Hare's system is intended to solve: "first, general ignorance and incapacity, or, to speak more 
moderately, insufficient mental qualifications, in the controlling body; secondly, the risk of its being under the influence of interests not identical with the general welfare of the community" (Considerations, C.W. XIX: 436).

Mill's remedy for the first risk is a parliament with men who personify the country's highest intelligence and virtue. The faith Mill holds in the process of deliberation leads him to consider the mere inclusion of several of such men to be of beneficial effect to an appropriate government of the nation. However, under the Originating system minorities remained without representation and majorities were misrepresented. He hoped that with Hare's system, morally solid and wise candidates could receive votes from the entire country, not only from their districts, and as a result, would have a high probability of being elected. Consequently, the party machinery would be forced to compete with those candidates and to select prestigious men to represent the party. The elite would reach the Parliament:

Hundreds of able men of independent thought, who would have no chance whatever of being chosen by the majority of any existing constituency, have by their writings, or their exertions in some field of public usefulness, made themselves known and approved by a few persons in almost every district of the kingdom; and if every vote that would be given for them in every place could be counted for their election, they might be able to complete the number of the quota. In no other way which it seems possible to suggest would Parliament be so certain of containing the very elite of the country. (Considerations, C.W. XIX: 456).

The second threat was the "danger of class legislation on the part of the numerical majority" (Considerations, C.W. XIX: 448). Mill was perfectly conscious that labouring men constituted the numerical majority of the country. He was in favour of giving them the right to vote, but only if such a resolution was accompanied by 
certain "checks". The checks were basically two: the Plural vote and, more importantly, the Hare system. Mill could sacrifice the first, but not the second (Letter to Max Kyllman, 1865, C.W. XVI: 998).

There is, in consequence, an obvious contradiction between the attribution of a proportionalist ideology avant la lettre to Mill, and his aversion to the possibility of class legislation. If it is true that the Hare system is a proportional system, and if Mill knew that workers were an unequivocal majority, then Mill should have been conscious of the danger. That he was not demonstrates that he simply did not understand the Hare system in that way. In fact, when he accepted to be a candidate for the House of Commons, he said that he would support a bill which "would give to the labouring classes a clear half of the national representation," but not more (Letter to James Beal, C. W. XVI: 1032). It is hard not to see here a direct refutation of the basic proportional principle.

Undoubtedly there are in Mill proportional expressions, but not a proportionalist philosophy. The approach and presuppositions of proportionalism are distant from his thought and perspective. His ideal of representative government is not the "mirror" of the people, but rather a vision of "guides" or, more appropriately, of a "self-guided people". Through representation, they are "self-improved". In contrast to Considerant, who thought that "every opinion, however absurd, even monstrous it may appear, must have its representatives in proportion to its strength in the electorate" (Hermens, 1941: 3), Mill did not aspire to represent/reflect everything in parliament—-true or false, noble or evil—but rather to represent/instruct. 


\section{4.- The weight of a paradigm}

Thomas Hare, the inventor of "the most proportional of systems" (Ryan, 2014:

11), wrote the following in response to certain interpretations of his proposal:

"Every detail of this scheme converges to one central point,- - that of making the exercise of the suffrage a step in the elevation of the individual character, whether it be found in a majority or a minority. I disclaim for it, therefore, the title of a representation of minorities" (Hare, 1873: XIX, emphasis added).

Paradoxically, the interpretation that has prevailed throughout has been the one that the author himself intended to avoid. The proportionalist reading has become authoritative. Mill is today the philosopher of proportionality, and the Hare system is currently considered as one of the best proportional systems. How has such an interpretation come about? I can only briefly put forward my hypothesis, leaving its complete development for another occasion. This hypothesis rests on two pivotal events.

The first is the historical formation of the Majority vs. Proportionality dichotomy, the frame which today dominates our conceptual approach to all electoral and representative issues. This dichotomy was forged around 1900, crystallized in 1941 with Hermens, and became canonical thanks to Duverger and his sociological laws. Once established, it provides the basic conceptual and terminological tools with which we look back.

Here I am only concerned with the historical genesis of one of the dichotomy's horns, the proportional one. In Mill's times, there were four alternatives to the Originating system, the four grouped under the "representation of the minorities" label: 21 
the Cumulative vote, the Limited vote, the Hare system and the Proportional Party List system (Bromund, 2001). This demand for the "representation of minorities" will become, over the period running from 1870 until approximately the end of the century, the claim for "proportional representation". Around 1900, the term "proportionality" refers indistinctly to the four electoral systems (Humphreys, 1911). The four conform the "proportional systems", not the "representation of minorities" systems 8 .

Compared to the Originating system, the four systems represent minorities in some manner. However only one (the Party List Proportional, defended by Considerant and Naville in Switzerland) is in fact "proportional" from an electoral perspective. Cumulative Vote and Limited Vote are majoritarian. The Hare system is, as we can say now, quotist. Mill's prestige and reputation were brandished in defense of all the alternatives to the Originating system. Such alternatives are going to configure one of

${ }^{8}$ Mill is probably the best exponent of this process, since he successively defended two of the four systems: the Cumulative Vote, in his Thoughts about Parliamentary Reform, and the Hare system, in his Considerations (Hart, 1992; Parsons, 2009). Indeed, at the end of chapter 7 of Considerations, he included under the "Personal representation" label all the contemporaneous alternatives to the Originating system. The problem is that those proposals are very different from each other. Mill cited the existing systems in Switzerland (Party List), in the USA (Cumulative List) and in Australia (the Hare System). Mill stressed that "the scheme is rapidly making its way". Too much rapidly, indeed. Early on, the expression "proportional" prevailed over the term "personal". In 1878, for example, the Spanish edition of the Considerations already translated "personal representation" into "proportional representation" (Mill, 1878). The same happened in several languages. See, for example, Petit Catéchisme de la Representation Proportionnelle, 1880, Belgium (anonymous). 
the horns of the dichotomy, that of the proportionality, and in consequence the authority of Mill is going to glide from his particular electoral system, the Hare system, to one of the two abstract principles of political representation, proportionality.

This is the first event of the hypothesis. The second arises when Mill is read in the light of this dichotomy. After Duverger, the Majority vs. Proportionality paradigm is omnipresent, and Mill tends to be read as the founder of the proportional archetype. In 1969, Pitkin (Pitkin, 1969, p. 21) compares the two representation models respectively headed by Burke and Mill. Her comparative assessment can be summarized as follows:

\section{BURKE}

\begin{tabular}{|c|c|}
\hline METAPOLITICS & REPRESENTATIVE'S ROLE \\
\hline $\begin{array}{l}\text { Representatives as superior in } \\
\text { wisdom } \\
\text { Political issues as having objective } \\
\text { solutions: deliberation } \\
\text { National interest }\end{array}$ & $\begin{array}{l}\text { Independence. Representative as a } \\
\text { trustee. }\end{array}$ \\
\hline
\end{tabular}

MILL

\begin{tabular}{|c|c|}
\hline METAPOLITICS & REPRESENTATIVE'S ROLE \\
\hline $\begin{array}{l}\text { Equality of capacity } \\
\text { Political issues as involving } \\
\begin{array}{l}\text { irrational commitment: "Choice rather } \\
\text { than deliberation" } \\
\text { Personal or local interests }\end{array}\end{array}$ & agent. \\
\hline
\end{tabular}

Although Pitkin herself indicates that identification of Mill with all the assertions in the table is not "complete," the problem is actually much deeper than this. Pitkin assumes that judgments relative to the role of representatives derive from the particular metapolitics sustained by each author. However the part of the table consigned to Mill seems to have been mediated by the electoral paradigm of proportionality, as if the lines have been dictated by what the paradigm establishes 
about "proportionality". The origin of those statements seems not to be Mill's texts, but the theoretical and abstract definition of "proportionality" as it appears in Political Science texts. Mill did not endorse the dependence of the representative: "the delegation theory of representation seems to me false, and its practical operation hurtful" (Considerations, C.W. XIX, p. 511). The other elements identified by Pitkin are equally debatable ${ }^{9}$.

Firstly, it is clear that the Hare system rendered obsolete the very concept of the geographical district, or, "locality" as a political component. Secondly, Mill did not believe in the equality of capacity between representatives and the represented. The equal vote is "in principle wrong by recognizing a wrong standard and exercising a bad influence on the voter's mind. It is not useful, but hurtful, that the constitution of the country should declare ignorance to be entitled to as much political power as knowledge" (Considerations, C.W. XIX, p. 477). This justification of an unequal vote is a consequence of the rather objectivist view that Mill held toward politics. As his friend Hare succinctly expressed, "after all, the end is good government" (Hare, 1873, p. xx).

Thirdly, there does not exist in Mill's thinking and writings the notion that political representation is merely a question of "choice rather than deliberation." In his view, "the voter is under an absolute moral obligation to consider the interest of the public, not his private advantage," (Considerations, C.W. XIX, p. 490). Indeed, Mill

${ }^{9}$ Thompson, (1976: 116) assigns Mill an intermediate position in the mandate-independence controversy. That is undoubtedly right, but here I do not want to situate Mill on that scale, but to illuminate why he is surprisingly situated on one of its ends. 
defended the Hare system not because of its "proportionality," but because of the absolute faith he had in the power of deliberation. He firmly believed that if honest and intelligent men reached parliament and could be heard, then reason and good sense would prevail. Mill wants all minorities to reach the parliament and be heard, not to give them more or less weight in proportion to their numbers of voters. His conception of political representation was based in deliberation, not in proportionality.

\section{5.- Proportionality without parties?}

Two consequences are worth highlighting. The first is related to Mill's philosophy. Mill scholars know perfectly that he was against parties and against the "representative as an agent" model. Yet they continue using the adjective "proportional" ascribed to his works. I think Political Science, and specifically the "Proportionality vs. Majority" paradigm, has played a role here. Mill scholars are not going to get confused, but people who have not studied Mill in as much depth are not as fortunate, because the term "proportional" has today its own underlying meaning. What Mill always defended was "Personal", not "proportional" representation. I do not see any reason to change his own words ${ }^{10}$.

${ }^{10}$ Specialists in Mill are aware that there is a difficulty here. Urbinati, for example, suggests that Mill intended an "elitist use of proportionality" (2000: 760). In my opinion, what is problematic is the customary use of the term "proportionality" still applied to Mill and Hare (Ryan, 2007: 165; Thompson, 2007: 175; Riley, 2007: 226; Kumar, 2013: 138; Ryan, 2014: 11). Maybe the use of the term "quotism" would result in a more accurate clarification of Mill's political thought. 
The second consequence has to do with the current classification of electoral systems. Political Science usually considers STV proportional to candidates, not to party lists. According to this, there is such a thing as a "proportional representation" not related to parties (or to racial or to ethnic groups, or to issues) but to persons. That is to say, a representation that is proportional and, at the same time, personal. As I understand it, that is not logically possible (not at long as one person can obtain only one seat). In all probability that is the reason why STV has always maintained a singular position and status in electoral classifications ${ }^{11}$. Unfortunately, this question cannot be addressed in this paper.

11 In 1910, the "Royal commission appointed to enquire into electoral systems" declared that STV "was not originally invented as a system of proportional representation" (1910: 35); in 1984, Dummett affirmed - correctly, in my understanding - that "STV is obviously a majority procedure" (1984: 280); in 2014, Farrell and Katz wrote that "in a technical sense it is a misnomer to identify STV as a proportional system at all” (2014: 13). 


\section{REFERENCES}

1880. Petit Catéchisme de la Representation Proportionnelle. Bruxelles: Ligue Reformiste Belge. Anonymous.

1910. Report of the Royal commission appointed to enquire into electoral systems, with appendices. London: House of Commons.

BAGEHOT, Walter. 1873. The English constitution. Boston: Little, Brown and co.

BROMUND, Ted. 2001. Uniting the whole people: Proportional representation in Great Britain, 1884-1885, reconsidered (Victorian liberalism and the building of "voluntary" communities during the Reform Crisis). Historical Research, 74(183), 7794.

BOWLER S., FARRELL D.M., PETTITT R.T. "Expert opinion on electoral systems: So which electoral system is 'best'?", Journal of Elections, Public Opinion \& Parties, 15, 2005.

COLOMER, Josep. 2001. Political institutions: democracy and social choice. New York: Oxford University Press.

COLOMER, Josep. 2007. On the Origins of Electoral Systems and Political Parties. Electoral Studies, 26(2), 262-273.

ECONOMOU, N. "Electoral reform and party system volatility: The consequences of the group vote ticket on Australian senate elections", Australasian Parliamentary Review, 31, 2016.

FARRELL D.M., KATZ R.S. "Assessing the proportionality of the Single Transferable Vote", Representation, 50, 2014.

HARE, Thomas. 1873. The election of representatives, parliamentary and municipal. A treatise (4th ed.). London: Longmans, Green, Reader, and Dyer.

HART, J. 1992. Proportional representation: critics of the British electoral system, 1820-1945. Oxford: Oxford University Press.

HERMENS, Ferdinand. 1941. Democracy or Anarchy? A Study of Proportional Representation. Indiana: University of Notre Dame.

HOAG, Clarence and HALLETT, George. 1926. Proportional representation. New York: The Macmillan company.

HUMPHREYS, J. H. 1911. Proportional Representation: A Study in Methods of Election. London: Methuen \& Company, Limited.

KUMAR, Sujith. 2013. Mill: a guide for the perplexed. A\&C Black.

LIJPHART A., GROFMAN B., Choosing an electoral system: issues and alternatives, Praeger, 1984.

MCLEAN, Ian. 1991. Forms of Representation and Systems of Voting. In Political Theory Today, edited by D. Held. London: Polity, pp. 172-196

MILL, John Stuart. 1878. Del Gobierno Representativo. Sevilla: Biblioteca científico-Literaria. 
MILL, John Stuart. 1963. Collected works. Toronto: University of Toronto Press.

MIRABEAU, Honoré Gabriel Riqueti, Comte de. 1789. Discours prononcé a la Tribune Nationale, Etats de Provence. In Oeuvres (Vol. 1) Edited by L. E. Pougin. Paris (1834).

MITCHELL P.: "The single transferable vote and ethnic conflict: The evidence from Northern Ireland", Electoral Studies, 33, 2014.

NAGEL J.H. "Proportional Representation". In: International Encyclopedia of the Social \& Behavioral Sciences, edited by NJ Smelser and PB Baltes. Oxford:

Pergamon, 2001; 12216-12219.

PARSONS, F.D. 2009. Thomas Hare and Political Representation in Victorian Britain. London: Palgrave Macmillan.

PITKIN, Hanna. 1969. Representation. New York: Atherton Press.

RILEY, Jonathan. 2007. Mill's Neo-Athenian Model of Liberal Democracy. In J. S. Mill's Political Thought, edited by N. Urbinati and A. Zakaras, A. New York:

Cambridge University Press, pp. 221-249.

RYAN, A. 2014. Mill, John Stuart (1806-73). In The Encyclopedia of Political Thought, edited by M. T. Gibbons.

RYAN, Alan. 2007. Bureaucracy, Democracy, Liberty: Some Unanswered Questions. In J. S. Mill's Political Thought, edited by N. Urbinati and A. Zakaras, A. New York: Cambridge University Press, pp. 147-165.

SKINNER, Quentin. 1969. Meaning and Understanding in History of Ideas. History and Theory, 8(1), 3-53.

SKINNER, Quentin. 2002. Visions of politics. New York: Cambridge University Press.

STERNE, Simon. 1871. On Representative Government and Personal Representation. Philadelphia: J. B. Lippincott \& co.

THOMPSON, D. F. 1976. John Stuart Mill and Representative Government. Princeton: Princeton University Press.

THOMPSON, Dennis. 2007. Mill in Parliament: When Should a Philosopher Compromise? In J. S. Mill's Political Thought, edited by N. Urbinati and A. Zakaras, A. New York: Cambridge University Press, pp. 166-199.

URBINATI, Nadia. 2000. Representation as advocacy. A study of democratic deliberation. Political Theory, 28(6), 758-786. 